\title{
A Case Study of College Teacher's Politeness Strategy in EFL Classroom
}

\author{
Liu Peng \\ School of Foreign Languages, Sichuan University of Science and Technology, Zigong, China \\ Fang Xie \\ School of Foreign Languages, Sichuan University of Science and Technology, Zigong, China \\ Lingling Cai \\ School of Foreign Languages, Sichuan University of Science and Technology, Zigong, China
}

\begin{abstract}
In the process of teaching and learning activity, teachers' language plays a very important role in EFL classroom, such as teachers' academic instructions, motivating the class and evaluating students. No exaggeration to say that teachers' language is indispensable to effective communication in class. Adopting Brown and Levinson's politeness strategies through class observation, the researcher aims to reveal how the teacher applies politeness strategies to his teaching practice in the language use. Through analyzing the data collected, the researcher finds out the college teacher conducts his class on term of positive politeness and negative politeness in a practical way. Evidently the adoption of politeness strategies shortens the teacher-student social distance, makes the class interesting, and in turn facilitates English teaching and learning.
\end{abstract}

Index Terms - application, positive politeness, negative politeness, EFL classroom

\section{INTRODUCTION}

In recent years, numerous scholars at home have conducted many researches on China college English teaching in various ways, such as the present situation and the direction of reformation. No matter where the reformation might go, it doesn't go without teachers' practical work without teachers' language used in the classroom. According to Numan (1991), teachers' language is of crucial importance, not only for the organization of the classroom, but also for the process of acquisition. Politeness is a common social phenomenon, and is regarded as a moral code in human communication and social activities. As we know, a positive learning atmosphere is encouraging both to teachers and students. Consequently it is of much importance to know about the extent in which how teachers apply politeness strategy to their language use in EFL classroom.

During the twelve years of EFL teaching at a west China university, I feel more and more puzzled. Why students show no more interest in English learning though its importance is especially stressed since the first day of their stepping into school? For each academic year's freshmen, better scores in the National College Entrance Exam (NCEE) don't encourage them to study harder in a more liberal college classrooms; instead, those scores become their primitive capital for future laziness at college. As a result, each year when freshmen's university days starts, I pay special attention to their response to each class, reflect on my teaching activities, and correct what might be inferred negative and destructive for their fragile enthusiasm in English class. What's more, I participate in my colleagues' class, learn about others' EFL teaching techniques, and most important of all, experience as much as how students want of English teachers and their class.

In a specific language learning environment, classroom activities hosted (not controlled, but guided) by teachers shapes like a special interpersonal relationship. It is similar to any other social relationship in that interlocutors have to work hard to promote their effective communication. What is the difference are teachers' dominant advantages in much of the communication as a result of their social status, knowledge and relative power. Random questions asked before class might prove something. Why don't you raise your hand since you know the answer? Why don't you stand up and correct teachers' wrong answers? Their answer is "I dare not because teachers look unapproachable" or "We are afraid to challenge teachers because they may be introducing 'new knowledge' though seemingly it is a wrong answer". This sounds ridiculous but it is understandable as teachers used to be "any of them".

\section{RELEVANT THEORIES}

\section{Brown and Levinson's Politeness Theory}

Politeness is a very important code of conduct in human society. In any social activity human language use has to obey this code too. Researches on politeness is closely related to Grice (1975), Leech (1983), and Brown and Levinson 
(1978, 1987). Among them, Brown and Levinson's politeness theory is claimed to be universally valid. Since the publication of their politeness research, many later researchers are following their track more or less. That is why the researcher builds its politeness research on it and tries to find out how college teachers apply politeness strategies in their language use.

Based on Goffman's (1987) notion of face, the core of Brown and Levinson's politeness theory (1978, 1987) is face-saving. They start from the idea of model persons, who are rational agents (1987:58). They think more strategically and are very conscious of their language choices. They have positive face and negative face, which are termed as the involvement and independence of face. According to Brown and Levinson, Face Threatening Acts (FTAs) are acts which inherently damage the addressee's (or the speakers') face against the wants and desires of the other. Everyone has his own face wants. Face is something that can be easily emotion-affected and can be saved, preserved, enhanced, lost or threatened and it must be constantly taken care of through interactions. Face is so tender and vulnerable that both participants in communication should try to save each other's faces. In this case, politeness strategies are employed to save the hearer's face when FTAs are unavoidable or unexpected. They (1978) formulate four politeness strategies and analyze four strategies: bald on record (without any redressive action), positive politeness (solidarity-seeking), negative politeness (freedom-given), and off record (indirect).

Normally in EFL classrooms, teachers are unavoidable to correct something that a student has said, done, or written. When this correction involves a negative evaluation of a student's trying, a face-threatening act happens. When the student is asked for further explanations, teachers' instructions might be a threat to him/ her because teachers are threatening the student's freedom of action, thus further threaten his/her negative face. Teachers' offering for help might also regarded as an FTA because it threatens students' negative face when teachers suggest that students may owe a debt to teachers and threaten students' positive face when teachers imply that students are in need of help.

\section{TeACHERS' LANGUAGE IN EFL ClassRoom}

\section{A. The Role of Teachers}

Started in the middle of 1990 s, researches on teachers have been carried on by many western scholars (TESOL Journal, 1994). Undoubtedly this trend shows that teachers play an important role in language teaching and learning. In China an ancient scholar Han Yu defined the role of teachers as "knowledge spreader, skill instructor, and problem solver". The advent of twenty-first century doesn't change the role of teachers intrinsically, but it requires the teachers to develop more qualities and traits. More specifically, the role of teachers is supposed to be a patient motivator, a helpful facilitator and a positive counselor.

\section{B. The Importance of Teachers' Language}

Since 1970s, lots of scholars both home and abroad have been conducting the studies of teachers' language. According to Rod Ellis (1985), teachers' language can be termed as teachers' talk, teachers' speech, or teachers' utterance, which is all about the language use in class. Flanders (1970) defines teaching activity as "acts by the teacher which occur in the context of classroom interaction". Hakansson (1986) and Ellis (1990) also claim the importance role of teachers' language in managing classroom interaction. Nunan (1991) illustrates the importance of teachers' language, both for the management of classroom and in the process of acquisition; for classroom management teachers' language may succeed or fail to carry out the teaching activities, while during the course of acquisition teachers' language is the major medium for understanding knowledge input that the learners are able to receive.

In EFL classroom teaching, English is not only the target language for students to learn, butt also a medium for teachers to teach English. EFL teachers are the models for the students to imitate while their language is the most important source for students to gain the knowledge of the language. Teachers' language is a language applied in a special language situation, while politeness is regarded as a most favorable strategy in interpersonal relationship. Combining Brown and Levinson's politeness strategy with teachers' language use, the researcher aims at what politeness strategies are applied in EFL classroom and how this combination facilitates teaching and learning activities and benefits both teachers and students.

\section{The Factors Affecting Teachers’'Application of Politeness Strategy}

In Brown and Levinson's theory, the strength or weightiness of a particular FTA (e.g. a request, an invitation, or a refusal) is the sum of these factors (1987, p.76-80): 1) social distance (D) between speaker and hearer, refers to the degree of familiarity and solidarity they share; 2) relative power $(\mathrm{P})$ of hearer over speaker in respect to hearer means the degree to which the speaker can impose his/her will on speaker; and 3) absolute rating $\left(\mathrm{R}_{\mathrm{x}}\right)$ of imposition in the culture, in terms of the expenditure of goods or services by hearer, the right of speaker to perform the act, and the degree to which the hearer welcomes the imposition.

$$
\mathrm{W}_{\mathrm{x}}=\mathrm{D}(\mathrm{S}, \mathrm{H})+\mathrm{P}(\mathrm{H}, \mathrm{S})+\mathrm{R}_{\mathrm{x}}
$$

(From Brown and Levinson, 1987, p.76)

Following Brown and Levinson, three factors are calculated to determine the weight of the FATs (i.e., the degree of 
risk to students' face) in the classroom context and are expected to influence its redress (i.e., the execution of politeness strategies). In the classroom context, teachers are supposed to have much knowledge and experience, they are the guiders in the classroom learning activities, and therefore to enjoy more authority over students and have more power than students. It is teachers' prevailing status in the classroom that brings on relatively great distance between teachers and students. However, the value of distance is changeable; teachers and students can be familiar with each other as time goes on. Rating of imposition in the classroom interaction is referred to as the degree of burdens that teachers put on students' shoulders or the extent of seriousness of any criticism or blame. With regard to EFL classrooms, when applying politeness strategies, the teacher should take three other factors into consideration. The first factor is age. It is easier to understand the younger a person is, the less awareness he/she has in term of politeness. The second one is students' ratio of gender. As Lakoff (1975) points out, women's language represents an overall conventional politeness. The more girls a class has, the higher degree of politeness is supposed to be used. The third is students' level of English proficiency. EFL context is a special place where non native language is used more frequently. The higher students' overall level of English proficiency, the better students can understand teachers' talk, and the higher awareness students may have in teachers' politeness strategy.

\section{Method and Data Collection}

EFL classrooms are special context for the application of politeness strategies in teachers' language. To better understand how the teacher conducts his class, I decided to collect data through non-participation class observation but recording the whole process of class activity in order that later on it is easier to pick out teachers' language used in class.

Since each academic year freshmen are younger and their English overall level is better (most students are lazy in learning English and thus their English is getting worse each semester at college.), I assume younger teacher are more conscious of the use of politeness strategies in class, and thus I observe two 45-minute classes given by a 30 -year-old male teacher. There are 30 students in his class, and their major is computer science. It is interesting but not strange 28 boys outnumber 2 girls, and boys nickname girls panda. The English class is about Generation Gap in Unit 2, New Horizon College English Book I. It is an easy and a popular topic among teenaged freshmen. The whole class the teacher designed many open questions like "how does the generation gap happen?" and "If you were a parent (a child), how can you solve possible problems with your children (parents)?" I was greatly infected by their friendly class environment.

In order to make teachers' language more specifically, after class observation when decoding the recording into written form, the researcher adopts the method used by Jiang Xiaoqing (2010). According to her, teachers' activities can be classified as four categories: 1) academic instructions, which shows how teachers direct students' learning activity, for example: the teacher's academic presentation, answering students' academic questions, and supportive and corrective feedback; 2) motivation, which refers to various illocutionary acts aimed at activating students such as their participation, academic questions, and initiative feedback; 3) evaluation, referring to teacher's positive and negative feedback which can encourage as well as discourage the students; and, 4) classroom management, which refers to disciplines of instructions or directives (orders, requests, questions, and calls), procedural instructions, and procedural directives). (Table 1, Table 2)

TABLE 1

POSITIVE POLITENESS IN TEACHERS' FOUR ACTIVITIES IN LANGUAGE

\begin{tabular}{|c|c|}
\hline \multicolumn{2}{|c|}{ Positive Politeness } \\
\hline $\begin{array}{l}\text { Academic } \\
\text { Instructions }\end{array}$ & $\begin{array}{l}\text { 1. Let's begin our class. } \\
\text { 2. Today we will learn Section A, Unit } 2 \text {. } \\
\text { 3. Could you please read New Words to us? } \\
\text { 4. Who would like to read New Words to the class? } \\
\text { 5. Please read carefully and find a similar word for "disgusting". } \\
\text { 6. Shall we move to the topic of the text? } \\
\text { 7. Talking about the generation gap, I think we all are familiar with this. } \\
\text { 8. Now I would like to ask one golden flower? Miss Xie, could you please give us an example of } \\
\text { different views over clothes (or make-up) between parents and children? }\end{array}$ \\
\hline Motivation & $\begin{array}{l}\text { 1. Would you like to answer this question? } \\
\text { 2. Why don't you translate what you are thinking about the generation gap into English? }\end{array}$ \\
\hline Evaluation & $\begin{array}{l}\text { 1. You all have done a wonderful job in New Words. } \\
\text { 2. All of you have done a perfect job. } \\
\text { 3. Excellent! } \\
\text { 4. Impressive! } \\
\text { 5. Keep working hard and good luck in next time's vocabulary quiz. }\end{array}$ \\
\hline $\begin{array}{l}\text { Classroom } \\
\text { Management }\end{array}$ & $\begin{array}{l}\text { 1. Quiet please! } \\
\text { 2. (Time is up!) Would you please stop talking? } \\
\text { 3. Now group discussion time. You three are group one. }\end{array}$ \\
\hline
\end{tabular}


TABLE 2

NegATIVE POLITENESS IN TEACHERS' FOUR ACTIVITIES IN LANGUAGE

\begin{tabular}{|c|c|}
\hline \multicolumn{2}{|c|}{ Negative Politeness } \\
\hline $\begin{array}{l}\text { Academic } \\
\text { Instructions }\end{array}$ & $\begin{array}{l}\text { 1. Now please read New Words after me. } \\
\text { 2. That's all for New Words. Please stop here. } \\
\text { 7. Now look at the blackboard and think about questions here. } \\
\text { 4. I appreciate your trying, but you are supposed to illustrate the problem-solving of the generation } \\
\text { gap. } \\
\text { 5. This question is kind of difficult. Please think carefully. } \\
\text { 6. That's all for the questions. Now I want you to do translation on page } 18 \text {. }\end{array}$ \\
\hline Motivation & $\begin{array}{l}\text { 1. Gentlemen please, what are your opinions? } \\
\text { 2. "Is my father enjoy classical music?" Maybe you can correct this sentence? } \\
\text { 3. I'm thinking, perhaps, you can have a try. }\end{array}$ \\
\hline Evaluation & 1. Well-done, Mr. Wang. You are a great father. \\
\hline $\begin{array}{l}\text { Classroom } \\
\text { Management }\end{array}$ & $\begin{array}{l}\text { 1. Now please practice this sentence structure with your desk-mate. } \\
\text { 2. You, please come here. } \\
\text { 3. Can you sit here? }\end{array}$ \\
\hline
\end{tabular}

When organizing the teacher's language, I was amazed (also in class) at student could manage to understand the teacher's difficult English sentences. The young male teacher is energetic, humorous and pro-English. So I decided to go back to his class, requesting that every student hand in a small piece of paper with their English score in the National College Entrance Exam (NCEE) but without their names on the paper. Studying their scores, I understand what I haven't before: I observed "good" students with an overall higher level of English proficiency. The total score for English NCEE is 150, and score 90 is "pass line". In China we measure 80-89 as "bad", 90-99 as "so-so", 100-109 as "O.K.", 110-119 as "good", 120-129 as "excellent" and 130-above as top (Table 2)

TABLE 2

DISTRIBUTION OF STUDENTS' SCORE IN NCEE

\begin{tabular}{|l|l|l|l|l|l|l|}
\hline Range of Scores & $80-89$ & $90-99$ & $100-109$ & $110-119$ & $120-129$ & $130-$ Above \\
\hline Number of Students & 2 & 11 & 7 & 8 & 2 & 0 \\
\hline
\end{tabular}

\section{DISCUSSION}

\section{A. The Application of Positive Politeness}

According to Brown and Levinson (1987) Positive politeness refers to any effort to meet a person's positive face wants, minimizing face-threatening acts to one's positive face in order that the speaker wants what the hearer's wants. For example: For example: No one can deal with this situation naturally like you can? We want you to stay with us. Could you still come along tomorrow? Speaker makes use of positive politeness in order to be consistent with hearer's positive face wants so as to satisfy hearer's positive face. During EFL classrooms teaching, appropriate strategies that the teacher adopts can help promote students' learning, help students know what they are doing and how to do it, reinforce proper learner behaviors and extend learning opportunities. Through class participation, I notice the teacher mainly adopted two positive strategies: the address and the compliment.

1. The address

e.g. Now I would like to ask one golden flower (In Chinese we have a famous film entitled Five Golden Flowers. Flowers symbolize pretty girls.). Miss Xie, could you please give us an example of different views over clothes (or make-up) between parents and children?

While calling the girl student's last name added Miss in front, the teacher walked to her seat with smiling face. He hit the target, the girl laughed with shyness, but she did a good job in answering the question.

e.g. Gentlemen please, what are your opinions? (Try to encourage boy students to participate voluntarily.)

Brown and Levinson define honorifics as "direct grammatical encodings of relative social status between participants, or between participants and persons or things referred to in the communicative event" (1987:179, 276). As we know, calling someone a name with respect (and nice jokes) makes him/her feel better and more important. In reality the address is determined by the interculators' social distance or relative power, while in the teacher's case, his address for students help establish an equal teacher-student status, build up their confidence and create a relaxing and friendly atmosphere for teaching and learning activities.

2. The compliment

In any culture where social face or individual face is of great significance, praises and compliments play a vital important in encouraging interpersonal relationships. As educators in traditional classroom teaching, the goal as teachers is to help students believe that they have the skills to succeed. The way teachers compliment students has an impact on how successful students perceive themselves. In the teacher's class, he never forgot to praise students with "positive" words like well-done, impressive, awesome and excellent. One funny thing in class was that after a boy student shared his opinions in how to solve different views over one thing with "his children", the teacher praised him with applause "Well-done, Mr. Wang. You are a great father." The whole laughed with joys. In China most youngsters are shy to act as "dad" or "mom" though when we are children we play the game of "mom-dad-child" family life. 
Afterwards more "father" or even "mother" stood up contributing their solutions to the generation gap with their child generation.

In general through class observation we see the teacher is quite aware of students' face wants. She takes the active attitudes towards her teaching language and tries to use appropriate words to show respect to her students and save their positive face.

\section{B. The Application of Negative Politeness}

Negative politeness can be similarly defined as any attempt to meet one's negative face wants, minimizing FTAs to one's negative face by means of speaker's retreat and avoidance of imposition on the hearer. For example: Could you please pass the paper to Mary? The speaker uses the formula of "Could you ...?"

Through class observation we can see hedges or questions are mostly used by the teacher to minimize the imposition. Hedge was first appeared in Lakoff's research paper. Brown and Levinson illustrate "hedges" as a "particle, word, or phrase that modifies the degree of membership of a predicate or noun phrase in a set; it says of that membership that it is partial, or true only in certain respects, or that it is more true and complete than perhaps might be expected (1987:145)". Hedges can soften performatives. Hedges may be encoded in particles or appear in form of adverbials like "in fact", "in a way" and "if" clauses, such as "if you want/can".

In the teacher's class terms, they have adopted many sentences with hedges.

e.g. Could you please read New Words to us?

e.g. Would you like to answer this question?

e.g. "Is my father enjoy classical music?" Maybe, you can correct this sentence?

e.g. I think, perhaps, you can have a try.

e.g. Now I want you to do translation on page 18 .

From the examples above, it is easy to understand the teacher's negative politeness strategy. Many of his sentence patterns are suggestive or added model verbs, which make the serious question-answer atmosphere less stressful, and students have more freedom of choices. For students' incorrect answers, the teacher gave a positive remark on the effort and then proposed his real thinking. e.g. I appreciate your trying, but you are supposed to illustrate the problem-solving of the generation gap. In this way students' face has been saved but the teacher hit the target to correct the student's mistake too.

\section{Further Discussion}

From Table 1, we can find out that positive strategy is preferable to negative strategy. Why does that happen? As we know, positive politeness is oriented towards an individual's positive self-image and emphasizes the need for association between teachers and students. By adopting more positive strategy, the teacher means to reduce the threat of FTAs and shorten the distance between them. As the teacher is getting to know her freshmen students, she wants to establish higher degree of familiarity with students.

In class the teacher uses many different linguistic means of positive politeness strategy in an attempt to claim common ground by seeking agreement, sharing interests and treating students as members of an in-group and friends. Besides, the teacher utilizes positive politeness strategy to claim association by virtue of the fact that teachers and students are cooperators in most cases. Positive politeness can make teachers satisfy students' positive face and save their negative face by offering help, asserting understanding of students' needs, showing sympathy for students when students have difficulties or when they suffer embarrassment.

\section{CONCLUSION}

Through the case study of a young male teacher's classroom activities, we notice that his classroom language is full of witty humor. Most importantly, we can conclude that teachers place much emphasis on the application of politeness strategies. As a young teacher, he succeeds in creating a comfortable language learning environment by using lots of positive politeness and negative politeness. He is skillful in: for one thing, using honorifics, cute addresses and encouraging compliments to stimulate students' learning enthusiasm, and build up their self-confidence; for another, he uses many hedges and questions to diminish the imposition and succeed in maintaining students' face.

\section{REFERENCES}

[1] Brown, P. \& Levinson, S. (1978). Universals in language use: politeness phenomena. In E.N. Broody (ed.). Questions and politeness: strategies in interaction. Cambridge: Cambridge University Press.

[2] Brown, P. \& Levinson, S. (1987). Politeness: Some universals in language usage. Cambridge: Cambridge University Press.

[3] Ellis, R. (1985). Understanding second language acquisition. Oxford: Oxford University Press.

[4] Ellis, R. (1985). Researching classroom language learning. In C.J. Brumfit and R. Mitchell (eds.). Research in the language classroom. Modern English Publications and the British Council.

[5] Flanders, N. A. (1970). Analyzing Teacher Behavior. Reading, MA: Addison-Wesley.

[6] Hakansson, G. (1986). Quantitative Studies of Teacher Talk. In Kasper (ed.). Learning, teaching and communication in the foreign language classroom. Aarhus: Aarhus University Press.

[7] Numan, D. (1991). Language teaching methodology: A textbook for teachers. Englewood Cliffs, NJ: Prentice Hall Inc., 
189-207.

[8] Xiongqing, Jiang. (2010). A case study of teacher's politeness in EFL class. Journal of Language Teaching and Research, 1, 651-655.

[9] Lakoff, Robin. (1975). Language and woman's place. New York: Harper \&. Row.

Liu Peng, was born in Chongqing, China in 1976. She received M.A. degree in applied linguistics from University of Electronic Science and Technology of Chengdu, China in 2012.

She is currently an English lecturer in School of Foreign Languages, Sichuan University of Science and Engineering, Zigong, China. Her research interests include EFL teaching and western culture.

Fang Xie, was born in Zhongxian, China in 1978. She received M.A. degree in applied linguistics from University of Electronic Science and Technology of Chengdu, China in 2012.

She is currently an English lecturer in School of Foreign Languages, Sichuan University of Science and Engineering, Zigong, China. Her research interest includes sociolinguistics.

Lingling Cai was born in Nanchong, China in1980. She received M.A. degree in European Culture from Sichuan University, China in 2011. From Feb-July 2010, she studied European Integration in Sabanci University (Istanbul, Turkey) as an exchange student in Erasmus Mundus Scholarships (Europe and China).

She is currently an English lecturer in School of Foreign Languages, Sichuan University of Science and Engineering, Zigong, China. Her research interests include European culture and vocational education of West China. 